Datum primitka članka u uredništvo: 20. 10. 2021.

Datum slanja članka na recenziju: 26. 10. 2021.

Datum prihvaćanja članka za objavu: 6. 12.2021.

Siniša Topalović, mag. oec.

\title{
DESTINATION MANAGEMENT ORGANISATION LITERATURE CATEGORISATION 2016-2020
}

\author{
KATEGORIZACIJA OBJAVLJENIH RADOVA \\ O DESTINACIJSKIM MENADŽMENTSKIM \\ ORGANIZACIJAMA OD 2016. DO 2020. GODINE
}

\begin{abstract}
Destination management organisations (DMO) are traditionally, and most commonly, part of public sector mechanism of tourism marketing and management in the specific area. As such, DMO has been under great research focus. Goal of this research is to analyse scientific research papers on DMOs, published in the period 2016 to 2020. Scientific articles published in 10 journals with highest Google Scholar h5-index in category "Business Economics and Management", subcategory "Tourism and Hospitality" have been analysed. Key findings of this research suggest that DMOs have been mostly researched in the area of their marketing function, followed by tourism policy. Other key responsibilities of DMOs, like strategic planning, market intelligence, digitalisation and innovation, investment promotion, crisis management, product development, training and HR development or DMO's efficiency have been just sporadically researched. With most of research focusing on Europe, and local DMOs, research gaps have been very precisely identified through this literature review.
\end{abstract}

KEYWORDS: destination management organisation, areas of research, research methods, implications, research gaps

JEL classification: Z3 Tourism Economics

SAŽETAK: Destinacijske menadžmentske organizacije (DMO) tradicionalno su, i najčešće, dio šireg javnosektorskog mehanizma marketinga i upravljanja turizmom na određenom području. Kao takve, predmetom su brojnih znanstvenih istraživanja. Cilj ovog rada jest analizirati znanstvene radove na temu destinacijskih menadžmentskih organizacija, objavljene u periodu od 2016. do 2020. godine. Analizirali su se znanstveni članci iz

Siniša Topalović, mag. oec., Global Head of Tourism Advisory, Horwath HTL, Slavonska avenija 1b, Business Park Matrix, 10000 Zagreb, Croatia, e-mail: stopalovic@horwathhtl.com 
10 časopisa s najvišim h5-indeksom Google Scholara u kategoriji „Poslovna ekonomija i menadžment”, potkategoriji „Turizam i ugostiteljstvo”. Ključni zaključci koji proizlaze iz ovog rada sugeriraju da je marketinška funkcija destinacijskih menadžmentskih organizacija bila najčešće istraživana tema, uz turističku politiku kao sljedeće područje. Ostale ključne odgovornosti DMO-ova, poput strateškog planiranja, poslovne inteligencije, digitalizacije i inovacija, promocije investicija, upravljanja kriznim situacijama, razvoja proizvoda, treninga i razvoja ljudskih resursa ili tema efikasnosti poslovanja DMO-ova, bile su samo sporadično istraživane. Uz glavni istraživački fokus na područje Europe i lokalnu razinu DMO-ova, ovom analizom objavljenih radova vrlo su jasno utvrđena deficitarna područja istraživanja.

KLJUČNE RIJEČI: destinacijske menadžmentske organizacije, područja istraživanja, metode istraživanja, implikacije, deficitarna područja istraživanja

\section{INTRODUCTION}

This research paper aims to more closely identify major research focus related to the topic of destination management organisations (hereinafter DMOs) due to the existing and increasing research body related to topics of destination management, destination marketing and destination branding, in particular since 2000 onwards (Morrison, 2013; Negrusa \& Coros, 2016), where number of published research papers reached 6,235 for the field of destination management, 7,954 research papers in the field of destination marketing and 2,526 research papers in the field of destination branding.

The emphasis of this research paper will be on categorisation of primary research focus of DMO-focused research papers. Thus, this research paper should bring more clarity and understanding which areas of DMO's operations have been most analysed as well as areas/functions of DMOs that did not get researchers' attention. The operational objective of this research paper, is therefore, to analyse the academic research of DMOs over last 5 years (i.e., 2016 to 2020) in most cited tourism and hospitality journals.

In particular, author will be focusing within this literature analysis to answer following key research questions, including but not limited to:

- Which DMO's functions have gained highest attention by academic researchers?

- Is the DMO-related research equally distributed among various geographies, or the topic is more characteristic to certain geographies?

- Do researchers more apply qualitative or quantitative research methods while researching DMOs?

- To which extent is the topic of DMO's efficiency represented in existing research papers?

- What are existing gaps in the field of DMO-related academic research?

Such research focus is novel as the existing DMO-related literature analysis papers have whether full focus on marketing function of DMOs, for instance Pike \& Page (2014a), or have had focus on content analysis of various published DMO research papers, for instance Jose Paul \& Varghese (2014), while this research paper will focus on categorisation of recently published DMO-related research papers. 


\section{DMO WITHIN THE RESEARCH LITERATURE}

Destination marketing and/or management organisations (DMOs) are undoubtedly a significant component of the tourism system (Hall \& Veer, 2016). Modern destination management organizations emerged in the Alpine countries in the second half of the $19^{\text {th }}$ Century and appeared almost simultaneously in the countries of the British Commonwealth (Beritelli \& Laesser, 2019). Thus, the destination management organisations are organisations that are in charge for executing various destination management roles that are stemming from destination visioning and tourism planning of a particular destination (Alastair M. Morrison, 2013). UN World Tourism defines destination management organisations in following way: "(DMO) is the leading organizational entity which may encompass the various authorities, stakeholders and professionals and facilitates tourism sector partnerships towards a collective destination vision. The governance structures of DMOs vary from a single public authority to a public/ private partnership model with the key role of initiating, coordinating and managing certain activities such as implementation of tourism policies, strategic planning, product development, promotion and marketing and convention bureau activities."

Given the history of tourism destination development it is interesting to consider that the published academic literature has only been around for 35 years (Pike, 2007). Even though, number of researches have been undertaken, it seems that many of them are focusing on very specific field of marketing and with more recent generation of researchers, on management as well. Field of DMOs is, undoubtedly, a potent field of academic research in tourism field, due to broad list of DMO's functions and responsibilities. According to UN World Tourism Organisation (UNWTO, 2019), some of fundamental DMO's functions include:

- Strategic planning

- Formulation (or participation in the formulation process) and implementation of the destination's tourism policy,

- Market intelligence (data gathering and analysis, market research, etc.),

- Tourism product and business development,

- Digitalization and innovation,

- Monitoring,

- Crisis management,

- Training and capacity building (not only of its human resources but also facilitate training and capacity building activities for local tourism professionals),

- Promotion, marketing and branding,

- Funding and fostering investments.

Such fundamental DMO's functions are to great extent aligned to DMO's roles identified by Wang (Wang \& Pizam, 2011) that include: Information provider, Community brand builder, Convener and facilitator, Catalyst, Advocate, Organizer, Funding agent, Partner and team builder, Network management organization.

DMOs are basic entities that realize the tourist policy of a given destination (Borzyszkowski, 2015) and large number of nations, states and cities are now founding DMOs as the 
main vehicle to compete and attract visitors to their distinctive place or visitor space (Pike $\&$ Page, 2014b). Destinations undertake marketing activities to brand and position a destination, and the results indicate that these activities are regarded as critical (Crouch, 2010). Therefore, the number of DMOs globally in continuously growing, and Professor Bob McKercher estimated its number during 2003 to over 10,000 (McKercher, 2003 in Pike, 2007).

With such broadly set functions that DMOs are responsible for on destination level and with ever increasing number of DMOs globally, the research focusing on categorisation of research papers in the DMO field is more than self-elaborative.

\section{METHODOLOGY}

Due to large number of tourism and hospitality academic journals, the literature scope of this research had to be properly focused. In order to do that, the author decided to utilise Google Scholar, more particularly to use Google Scholar h5-index as an indicator of research impact metric. H5-index is the h-index for articles published in the last 5 complete years. It is the largest number $\mathrm{h}$ such that $\mathrm{h}$ articles published in 2016-2020 have at least $\mathrm{h}$ citations each (Google Scholar, 2021').

Journals from the category "Business, Economics \& Management", subcategory "Tourism \& Hospitality" have been taken into account. The subcategory consisted of 20 journals, out of which highest ranked "Tourism management" scored h5-index of 118, while lowest ranged journal "Scandinavian Journal of Hospitality and Tourism" scored h5-index of 30 . The author decided to focus on top 10 journals according to h5-index value, including: Tourism Management, International Journal of Hospitality Management, International Journal of Contemporary Hospitality Management, Journal of Travel Research, Annals of Tourism Research, Current Issues in Tourism, Journal of Sustainable Tourism, Tourism Management Perspectives, Journal of Destination Marketing \& Management and Journal of Travel \& Tourism Marketing.

Every of 10 journals has been searched using "destination management organisation" and "destination management organization" as the search terms from year 2016 to year 2020 , resulting with initial list of 292 articles. Due to large initial number of articles, author started the process of abstracts screening in order to identify those articles where DMOs have been the primary focus of the article. Namely, there is large number of research articles in which destination management organisations are mentioned to greater or lesser extent since DMOs execute various destination marketing functions. However, such articles where DMOs are not primary focus of the research paper, have not been shortlisted for detailed analysis.

After conducted shortlisting, total of 35 articles have been identified in order to ensure precise focus on identifying exact research areas or DMO-related research papers. 
Table 1: Summary of literature research per journal

\begin{tabular}{|c|l|c|}
\hline$\#$ & \multicolumn{1}{|c|}{ Journal } & $\begin{array}{c}\text { Number of } \\
\text { selected } \\
\text { articles }\end{array}$ \\
\hline 1 & Journal of Destination Marketing \& Management & 13 \\
\hline 2 & Tourism Management Perspectives & 6 \\
\hline 3 & Annals of Tourism Research & 4 \\
\hline 4 & International Journal of Contemporary Hospitality Management & 4 \\
\hline 5 & Current Issues in Tourism & 3 \\
\hline 6 & Tourism Management & 3 \\
\hline 7 & Journal of Travel \& Tourism Marketing & 2 \\
\hline 8 & International Journal of Hospitality Management & 0 \\
\hline 9 & Journal of Sustainable Tourism & 0 \\
\hline 10 & Journal of Travel Research & 0 \\
\hline & TOTAL & 35 \\
\hline
\end{tabular}

Source: Author's research, 2021

Following initial shortlisting, detailed analysis of the papers has been conducted. Detailed analysis consisted of manual coding of each of the shortlisted papers:

- Paper title - title under which research paper was published

- Author(s) - one or multiple authors of the published research paper

- Year - year of publication of the research paper

- Page count - length of research paper, measured in number of pages

- Journal - journal in which the research paper has been published

- DMO level - definition whether DMO in the research paper is of national, regional or local level - coding applied consisted of "N" for national-level DMO, "R" for regional-level DMO, "L" for local-level DMO and "N/A" when not applicable

- DMO specification - more particular data on the specifics of the DMO researched where details on name of DMO, destination(s) included in the analysis or other DMO descriptors have been noted

- Research method - denominates whether the research paper applied quantitative or qualitative research method, or both methods

- Sample size - details on sample size used in the research paper

- Research primary focus - identification of the primary focus of the research according to the predefined DMO functions: "Strategic Planning", "Tourism Policy", "Promotion, Marketing and Branding", "Market Intelligence", "Digitalisation and Innovations", "Tourism Product and Business Development", "Monitoring", "Crisis Management", "Training \& Capacity Building" and "Funding and Fostering Investments". DMO functions have been adopted from the UNWTO's publication "Guidelines for Institutional Strengthening of Destination Management Organizations (DMOs) - Preparing DMOs for new challenges" in order to apply one of most recent/accurate classifications of DMO functions (UNWTO, 2019). One additional perspective was added, being "DMO Efficiency" where author wanted to clarify to 
which extent DMO-related research papers do analyse efficiency of DMO's operations according to defined objectives of this research, as elaborated in the introductory section. In such way, author created the 11 categories under which analysed papers will be categorised.

One research paper can be categorised under more than one category, should the research topic justify multiple categorisation - for instance a research paper dealing with digital innovation in the field of destination marketing, in which case the paper would be categorised as "Promotion, Marketing and Branding" and "Digitalisation and Innovations".

The shortlisted 35 papers have been presented in the Table 2: Summary of Destination Management Organisation Studies 2016-2020. 
Table 2. Summary of Destination Management Organisation Studies 2016-2020

\begin{tabular}{|c|c|c|c|c|c|c|c|c|c|c|c|c|c|c|c|c|c|c|c|}
\hline & & & & & & & & & & & & & & rch primary & focus & & & & \\
\hline \# & Title & Author(s) & Year & $\begin{array}{l}\text { Page } \\
\text { count }\end{array}$ & Journal & $\begin{array}{l}\text { DMo } \\
\text { level }\end{array}$ & $\begin{array}{l}\text { DMO } \\
\text { specification }\end{array}$ & $\begin{array}{l}\text { Research } \\
\text { method }\end{array}$ & Sample size & 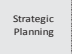 & 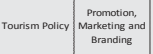 & $\begin{array}{c}\text { Market } \\
\text { metelleance }\end{array}$ & 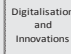 & 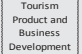 & Monitoring & 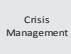 & 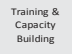 & 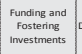 & ono effricienct \\
\hline 1 & $\begin{array}{l}\text { Facebook as a destination } \\
\text { marketing tool: Evidence from } \\
\text { Italian regional Destination } \\
\text { Management Organizations }\end{array}$ & $\begin{array}{l}\text { Marcello M. Mariani, } \\
\text { Marco Di felice, } \\
\text { Matteo Mura }\end{array}$ & 2016 & 22 & \begin{tabular}{|l|} 
Tourism \\
Management
\end{tabular} & $\mathrm{R}$ & \begin{tabular}{|l|}
19 Italian \\
regional DMOs
\end{tabular} & $\begin{array}{l}\begin{array}{l}\text { Qualitative } \\
\text { and } \\
\text { quantitative }\end{array} \\
\end{array}$ & 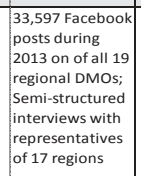 & & $x$ & & & & & & & & \\
\hline 2 & $\begin{array}{l}\text { DMO online plattorms: Image } \\
\text { and intention to visit }\end{array}$ & \begin{tabular}{|l} 
Sebastian Molinillo, \\
Francisco Liebana- \\
Cabanillas, Rafael \\
Anavaz-Sanchezz, \\
Dimitrios Buhalis
\end{tabular} & 2018 & 14 & $\begin{array}{l}\text { Tourism } \\
\text { Management }\end{array}$ & $\mathrm{N}$ & \begin{tabular}{|l} 
Indonesia, \\
Austria, Norway, \\
Turkey, The \\
Netherlands
\end{tabular} & Quantitative & $\begin{array}{l}272 \text { university } \\
\text { students }\end{array}$ & & $\mathrm{x}$ & & & & & & & & \\
\hline 3 & $\begin{array}{l}\text { An examination of DMO network } \\
\text { identity using Exponential } \\
\text { Random Graph Models }\end{array}$ & $\begin{array}{l}\text { Dean Hristov, Nigel L } \\
\text { Williams }\end{array}$ & 2018 & 9 & $\begin{array}{l}\text { Tourism } \\
\text { Management }\end{array}$ & & \begin{tabular}{|l} 
Destination \\
Milton Keynes, \\
UK
\end{tabular} & Quantitative & $\begin{array}{l}\text { Undisclosed } \\
\text { number of } \\
\text { network survey } \\
\text { questionnaires }\end{array}$ & & & & & & & & & & \\
\hline 4 & $\begin{array}{l}\text { The power of social media } \\
\text { storytelling in destination } \\
\text { branding }\end{array}$ & $\begin{array}{l}\text { Niels Frederik Lunda, } \\
\text { scott A. Cohen, } \\
\text { caroline Scarles }\end{array}$ & 2018 & & $\begin{array}{l}\text { Journal of } \\
\text { Destination } \\
\text { Marketing \& } \\
\text { Management }\end{array}$ & N & VisitDenmark & Qualitative & $\begin{array}{l}\text { questrontries } \\
25 \text { posts }\end{array}$ & & x & & & & & & & & \\
\hline 5 & $\begin{array}{l}\text { What content to post? Evaluating } \\
\text { the effectiveness of Faceboook } \\
\text { communications in destinations }\end{array}$ & $\begin{array}{l}\text { Arturo Molina, Mar } \\
\text { Gounez, Andrew Lyon, } \\
\text { Evangelina arandac, } \\
\text { Wilhelm Loibl }\end{array}$ & 2020 & 11 & $\begin{array}{l}\text { Journal of } \\
\text { Destination } \\
\text { Marketing \& } \\
\text { Management }\end{array}$ & L & 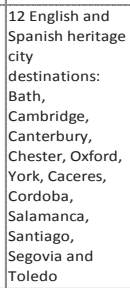 & Quantitative & $\begin{array}{l}\text { 3,303 posts on } \\
\text { DMOS' Facebook } \\
\text { pages by DMMOs }\end{array}$ & & x & & & & & & & & \\
\hline 6 & \begin{tabular}{|l} 
Destination cobranding in \\
interorganizational networks: \\
Assessing the role of central \\
tourism organizations
\end{tabular} & $\begin{array}{l}\text { Jarle Aarstad, Hảvard } \\
\text { Ness, Sven A. } \\
\text { Haugland }\end{array}$ & 2020 & & $\begin{array}{l}\text { Journal of } \\
\text { Destination } \\
\text { Marketing \& } \\
\text { Management }\end{array}$ & R & $\begin{array}{l}\text { Norwegian } \\
\text { region of nine } \\
\text { winter sports } \\
\text { destinations }\end{array}$ & Quantitative & $\begin{array}{l}990 \text { dyadic } \\
\text { observations }\end{array}$ & & & & & & & & & & \\
\hline & $\begin{array}{l}\text { Are alpine destination } \\
\text { management organizations } \\
\text { (DMOS) appropritite entities for } \\
\text { the commercialization of summer } \\
\text { tourism products? }\end{array}$ & Katarzyna Klimek & 2018 & & $\begin{array}{l}\text { Journal of } \\
\text { Destination } \\
\text { Marketing \& } \\
\text { Management }\end{array}$ & $L, R$ & $\begin{array}{l}125 \text { mountain } \\
\text { DMOs from } \\
\text { Austria } \\
\text { Switzerland, } \\
\text { Germany and } \\
\text { France: } 55 \text { local } \\
\text { and } 70 \text { regional }\end{array}$ & Quantitative & $\begin{array}{l}\text { Dataset of } 125 \\
\text { mountain DMOS } \\
\text { websites }\end{array}$ & & & & & x & & & & & \\
\hline & $\begin{array}{l}\text { The determinants of facebook } \\
\text { social engagement for national } \\
\text { tourism organizations' Facebook } \\
\text { pages: A quantititative approach }\end{array}$ & $\begin{array}{l}\text { Marcello M. Mariani, } \\
\text { Matteo Mura, Marco } \\
\text { Di Felice }\end{array}$ & 2018 & 13 & $\begin{array}{l}\text { Journal of } \\
\text { Destination } \\
\text { Marketitg \& } \\
\text { Management }\end{array}$ & N & \begin{tabular}{|l}
10 most visited \\
countries by \\
international \\
tourists
\end{tabular} & Quantitative & 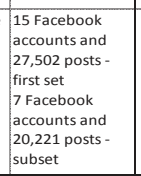 & & & & & & & & & & \\
\hline
\end{tabular}




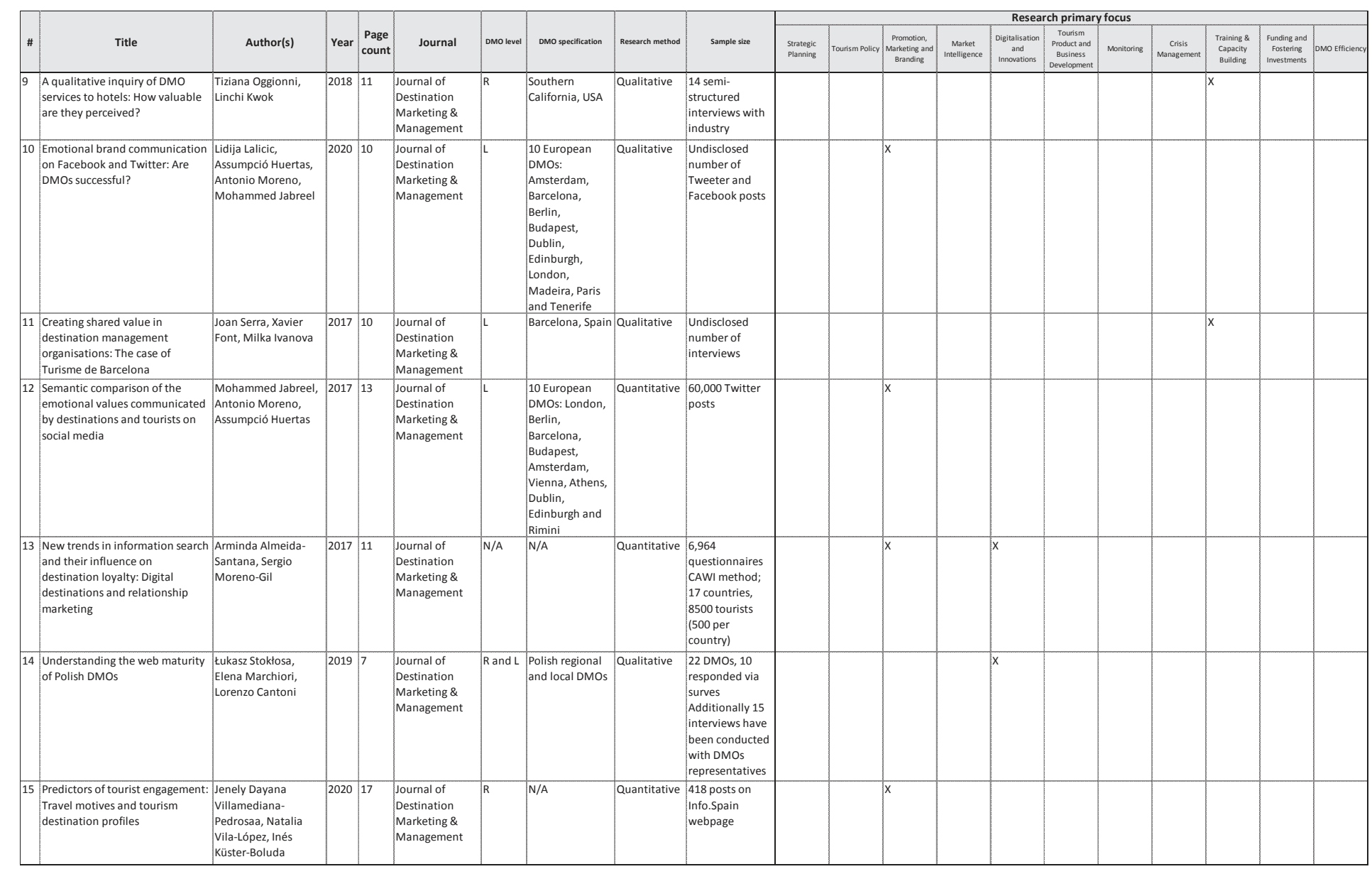




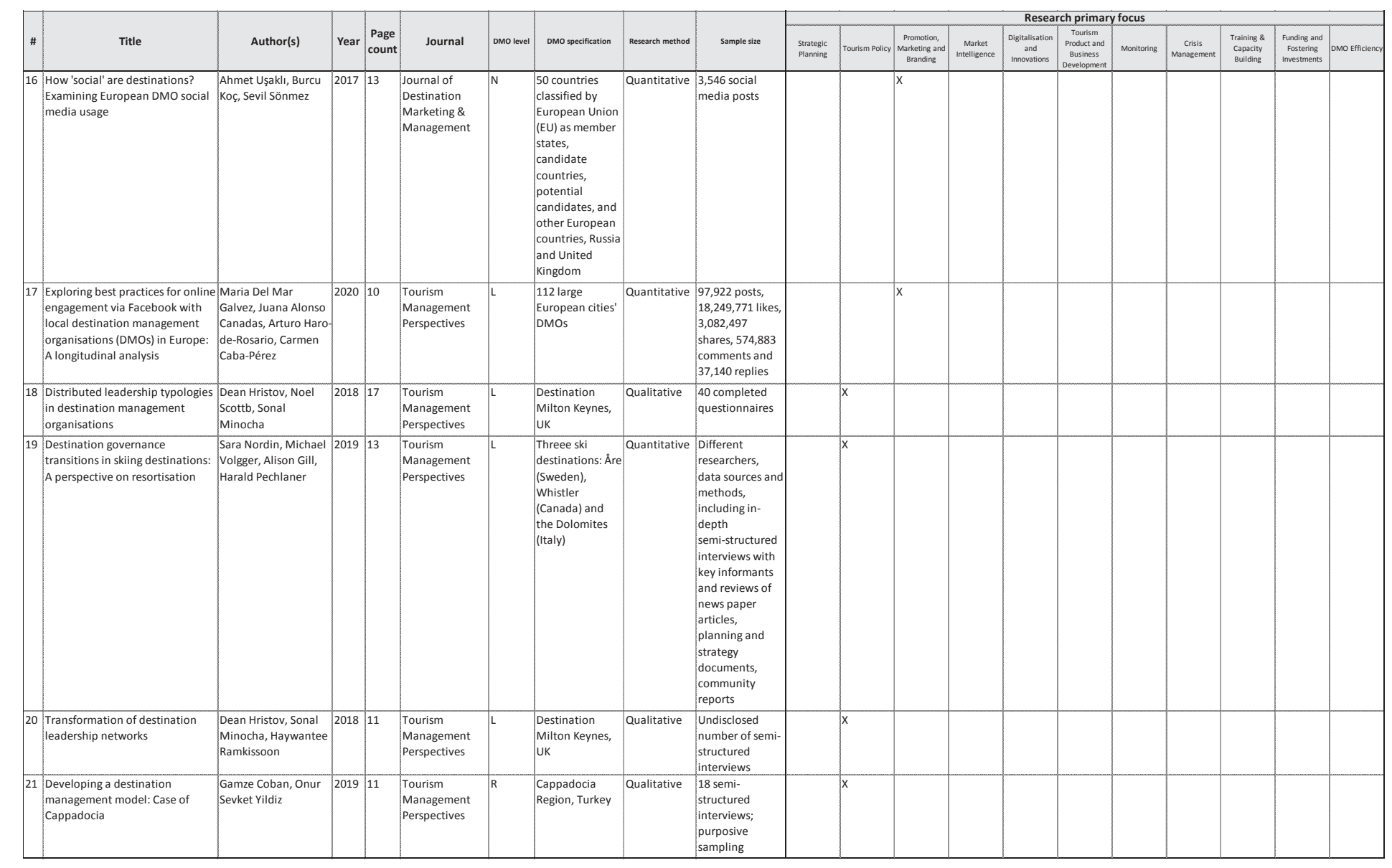




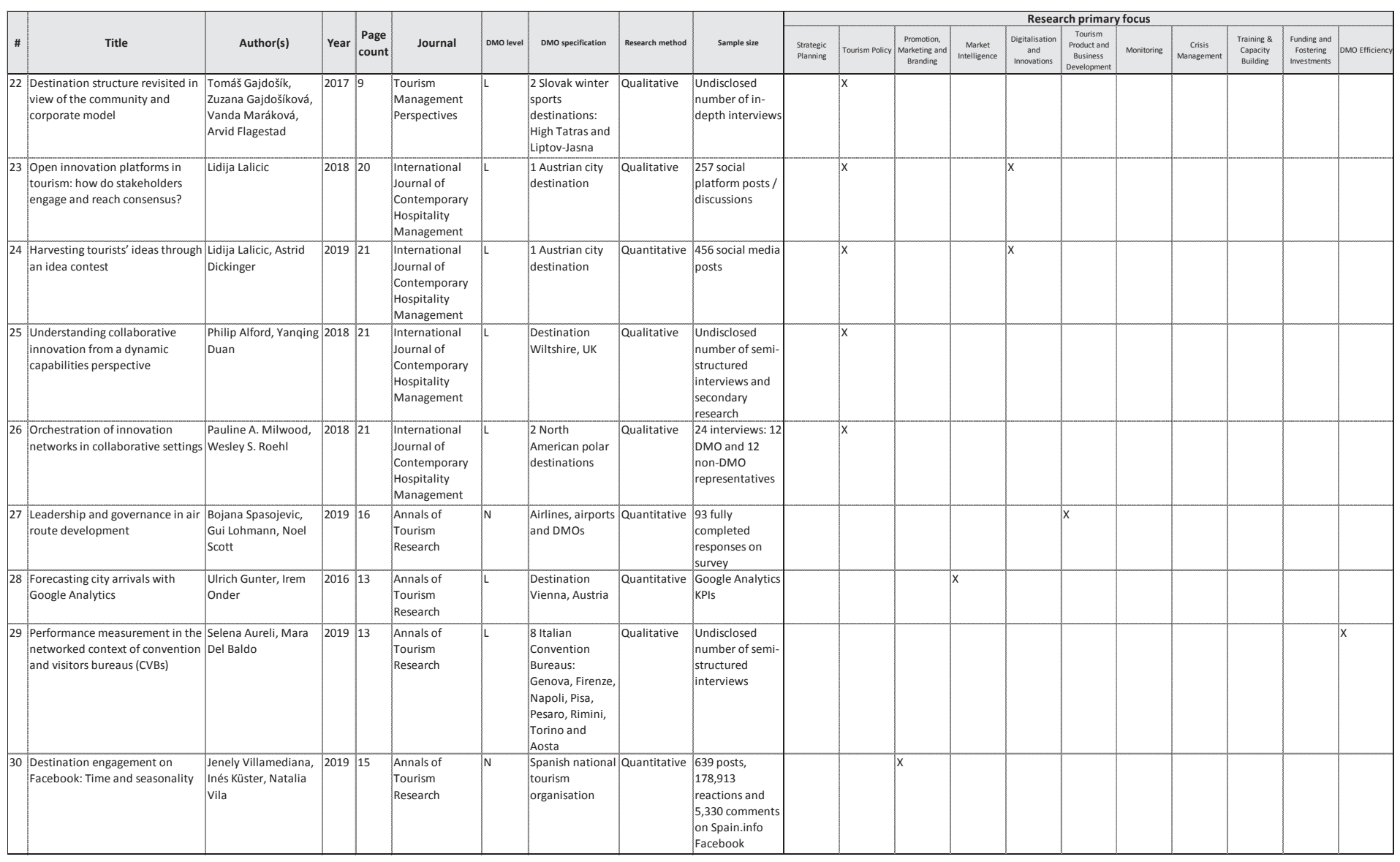




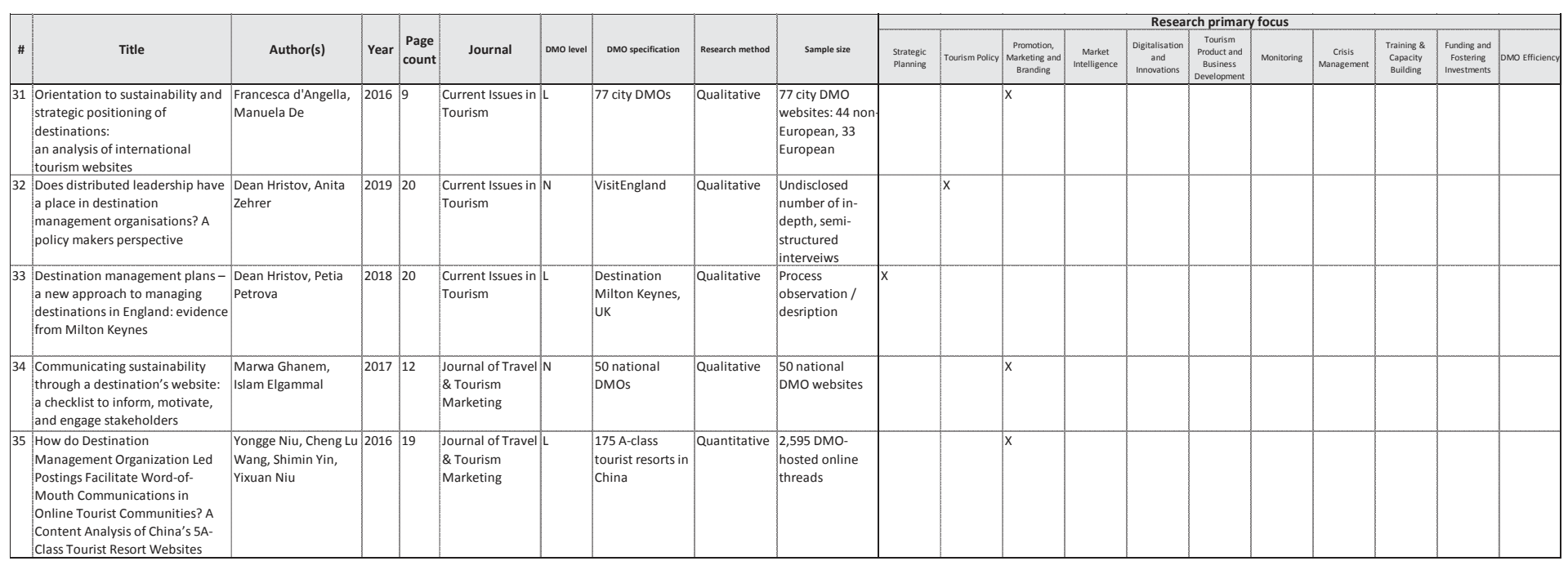

Source: Author's research, 2021 


\section{FINDINGS}

Based on the conducted analysis of 35 research papers, it can be concluded that UNWTO's classification of DMO's key functions, in addition to author's addition of "DMO efficiency" dimension, proved to be a comprehensive classification of DMO's functions since all of the research papers dealing with DMOs could have been allocated to one, or several, preidentified DMO functions. Consequently, there was no need for additional functions to be defined by the author during the course of the detailed analysis.

Single richest source of research papers related to DMOs, according to the applied research methodology, is Journal of Destination Marketing \& Management with 37\% of all research papers coming from this source. Following source is Tourism Management Perspectives with 17\%, Annals of Tourism Research with 11\%, International Journal of Contemporary Hospitality Management with $11 \%$ of all research papers analysed in this paper. Current Issues in Tourism contained 9\%, Tourism Management $9 \%$ and Journal of Travel \& Tourism Marketing 6\% of the analysed papers. Remaining three journals, namely International Journal of Hospitality Management, Journal of Sustainable Tourism and Journal of Travel Research contained no articles on DMOs under the applied research methodology. Therefore, according to this research, Journal of Destination Marketing \& Management is the most likely to publish DMO-focused articles among 10 journals with highest Google Scholar h5-index in category "Business Economics and Management", subcategory "Tourism and Hospitality".

Over the analysed 5-years period, year 2016 saw 4 published research papers, year 2017 saw 6 research papers, year 2018 saw 12 research papers, year 2019 saw 8 research papers, while 5 research papers have been published in 2020.

Among analysed research papers, 19 researched local level DMOs, 8 researched national level DMOs and 5 researched regional level DMOs. Thus, more than $50 \%$ of all papers dealt with local level DMOs. In addition, 2 papers researched regional and local level DMOs, while 1 paper did not research any particular level, but was focusing on providing inputs for any DMO level. Thus, the most common level or DMO research is focusing on local level DMOs.

Analysing the geographical focus of the research papers, large majority of $71 \%$ of analysed papers focused their DMO research on Europe, 17\% or the research papers analysed DMOs from different continents, thus classified as "Intercontinental", $6 \%$ of research papers analysed DMOs from North America and 6\% from Asia. Thus, the highest research interest in the field of DMOs is recorded in Europe, followed by intercontinental studies involving DMOs from multiple continents.

Research papers on DMOs were equally using qualitative and quantitative research methods. Namely, 17 research papers (48.6\%) applied quantitative research method, 17 research papers (48.6\%) applied qualitative research method, while 1 paper (2.9\%) applied both methods. Therefore, it can be concluded that research in the field of DMO equally applied qualitative and quantitative research methods in researching DMO topics.

Depending on the research method, sample size varied significantly across research papers. From as high as 97,922 Facebook posts focusing on 112 large European cities, 60,000 Tweet posts related to 10 European city destinations or 33,597 Facebook posts related to 19 Italian regional DMOs to as low as 14 questionnaires with industry practitioners 
in Southern California or 18 semi-structured interviews in Cappadocia Region in Turkey. Interestingly, 8 research papers or $23 \%$ or analysed research papers, did not disclose sample sizes on which research was conducted.

The author identified 10 broader thematic areas, according to which research papers have been classified. Several papers, duet to their dual focus, have been categorised in two thematic areas. Thematic area that induced highest research interest was area of "Promotion, marketing and branding" with 16 research papers, or $42 \%$ or all analysed research papers. Second most popular thematic area was "Tourism policy" with 11 research papers, or $29 \%$ of analysed research papers. Third most engaging thematic area was "Digitalisation and innovations" with 4 research papers, or $11 \%$ of analysed research papers. Top three thematic areas comprise $82 \%$ of research papers. Thematic areas of "Tourism product and business development" and "Training \& capacity building" both recorded 2 research papers, or each of them 5\% of the research papers. Thematic areas "Strategic planning", "Market intelligence" and "DMO Efficiency" recorded 1 research paper each, or 3\% of the analysed research papers each. Thematic areas "Monitoring", "Crisis management" and "Funding and fostering investments" have not been researched in context of analysed DMO research papers. It can be concluded that DMO researches dominantly focused on topics related to promotion, marketing, branding, tourism policy and digitalisation.

Within the thematic area of "Promotion, marketing and branding", most popular topics involved:

- Social media marketing with 12 of 16 research papers within this thematic area; or $75 \%$ of all research papers within this thematic area,

- Online platforms with 2 of 16 research papers within this thematic area; or 13\% of all research papers within this thematic area, and

- Cobranding with 1 of 16 research papers within this thematic area; or $6 \%$ of all research papers within this thematic area.

- Sustainability with 1 of 16 research papers within this thematic area; or $6 \%$ of all research papers within this thematic area.

Research topics within this thematic area are very much homogenous and concentrated around social media marketing due to technological advancement enabling collecting and processing large amounts of social media-generated data.

Within the thematic area of "Tourism policy", most popular topics involved:

- Innovation with 4 of 11 research papers within this thematic area; or $36 \%$ of all research papers within this thematic area,

- Destination leadership with 4 of 11 research papers within this thematic area; or $36 \%$ of all research papers within this thematic area, and

- Destination governance with 3 of 11 research papers within this thematic area; or $27 \%$ of all research papers within this thematic area.

Research topics within this thematic area are more diversified and almost equally distributed among three areas important in terms of destination management, being innovation, leadership and governance.

Within the thematic area of "Digitalisation and innovations", most popular topics involved digital transformation, web maturity and digital innovation discussion platforms. 
Average research paper length amounted 13.7 pages, with 22 pages being the longest research paper and 7 pages being shortest research paper.

\section{IMPLICATIONS AND DISCUSSION}

\section{Yes, marketing...but what else?}

Based on the conducted research, it can be concluded that majority of DMO-related research papers focus on marketing and to lesser extent management perspectives. It seems that regardless of the fact that there is abundance of research articles, that there is lack of variety and very narrow research focus in the existing DMO-related academic research. Number of DMO's functions and responsibilities are neglected from research point of view, for various potential reasons, including but not limited to: lack of transparency, lack of data, lack of cooperation, hype around social media big data and data crawlers etc.

It is interesting to note that almost no research has been conducted in the field of efficiency of DMOs. Regardless of the fact that there is increasing debate on DMO's roles and true impact on destinations (e.g. Pike \& Page, 2014a or Beritelli \& Laesser, 2019). There have been published certain research papers that focused on DMOs in the United Kingdom, following the introduction of 2011 Government Tourism Policy (for instance Hristov \& Petrova, 2018). Hristov \& Petrova (2018) highlighted that here is evidence of a challenging economic context, a significant change in the way tourism is managed and reduced government funding, combined with a broader mandate for DMOs. So, DMOs have been expected to secure their own long-term financial stability, and concurrently to establish and coordinate collaborative partnerships, including a range of local and regional actors from the public, private and not-for-profit sectors.

In order to perform better or to create better conditions for success, destinations must actively form and manage governance structures and their mechanisms (Beritelli et al., 2007), therefore the areas of strategic planning, digitalisation, market research and business intelligence, product development, investment promotion, DMO efficiency, Industry training and destination collaboration represent significant space for further research with both theoretical and practical implications and value.

\section{Local is good...but there is lack of national level view}

With more than $50 \%$ of research papers focusing on local level DMOs, it is rather evident that other DMO levels are not getting appropriate research attention. Namely, only $23 \%$ or analysed research papers dealt with national level DMOs. National level DMOs are increasingly market-oriented organisations which, by virtue of their culture and values, perform better in competitive markets (Wight, 2013) which was confirmed by strong research focus on their marketing role, however, other dimensions of NTOs functions or efficiency assessment have been neglected in the analysed research papers.

Since DMO's tasks and responsibilities significantly vary between local, regional and national levels, it is important to obtain scientific insights on every of mentioned levels. For instance, while local levels have to do more with local stakeholders, product development and destination branding; national level DMOs deal to greater extent with international 
promotion, national-level business intelligence, sectorial digital transformation, investment promotion and capacity building, among other things (UNWTO, 2007).

\section{Point in time more than a longitudinal approach}

Majority of the analysed research papers have looked at DMOs in particular point in time. Just few of research papers did apply a longitudinal approach. Considering that fact, looking at DMO topics via a longitudinal research approach could result with number of practical findings and implications of DMO's impact on destination development. Such approach could result with valuable findings when studying destination performances and DMO's influences on them, for instance.

\section{Lack of financially-driven research}

Only one research paper, among all analysed research papers, was dealing with question of DMO efficiency, while not a single on research paper did research financial aspects of DMOs. It is interesting to notice that even earlier researches (Bornhorst et al., 2010) highlighted the same issue, i.e., the nature of financing and financial management within DMOs, although a crucial topic, is not getting adequate attention. European DMOs disposed with more than 750 million Euros (European Travel Commission, 2018), out of which over half budget allocation is spent on marketing. Analysed research papers that did research marketing function of DMOs, did not tackle financial aspects of marketing activities either.

Therefore, future research of DMO's financial aspects could result with substantially interesting and useful academic and practical findings, especially since there is lack of transparent benchmarking in the field of DMO operations. With such lack of transparency, it is not surprising that there is an entire generation of tourist professionals, both professionals and academics, that are indoctrinated by theories that do not reflect the reality or are truth to rather limited extent, about which Beritelli \& Laesser (2019) discussed in their critical comment on DMOs roles and responsibilities.

Therefore, further research focusing on measuring the efficiency of DMO's operations and qualifying and quantifying DMO's real effect on destination development and performances will represent a major contribution in the DMO research field, as opposed to rather "abused" research area of destination marketing with specific focus on social media.

\section{Europe, Europe, Europe}

With more $70 \%$ of all analysed research papers focusing on Europe, it is evident that DMOs in other geographies are not as researched as European ones. Although Europe is considered as the DMO's stronghold (Beritelli \& Laesser, 2019), number of non-European DMOs do represent particularly interesting subject of research, especially to compare existing studies on European DMOs with similar or the same ones on non-European in order to create additional body of knowledge through comparisons. 


\section{SUMMARY}

It is important to emphasise that this literature review does not claim to be a comprehensive, complete overview of all research papers on DMOs in last five years; but rather a selective analysis of DMO research papers in most cited academic journals in the field of "Tourism and Hospitality" with highest five-year h-index on Google Scholar.

To the author's knowledge, there is no similar analysis for longer time series, that would focus on areas of research within DMO topic. Therefore, this could be the avenue for further research through understanding of the evolution of DMO-related research topics within academic research over several decades.

In addition to the above, significant DMO-centric research gaps have been identified in the areas of strategic planning, digital transformation, market intelligence, operational efficiency, crisis management, monitoring, product development as well as fostering investments. All of those areas are subject of daily business of many DMOs, but from academic research point of view, have not gained significant attention.

As digital transformation is becoming inevitable reality of all tourism stakeholders (Dredge et al., 2018), increasing focus on this are could generate number of very useful findings and body of knowledge, both for practitioners and academics alike, especially since DMOs still have not so much dived into the practicalities of digital transformation.

Additionally, research efforts in the field of benchmarking DMO's key performance indicators on national, regional and local level could confirm their academic and practical value.

It should be acknowledged that this review did not cover various elements/details of existing research papers, for instance specified method of qualitative or quantitative research applied, which might be of interest for future research related to DMO-focused research.

\section{REFERENCES}

1. Aarstad, J., Ness, H., \& Haugland, S. A. (2020). Destination cobranding in interorganizational networks: Assessing the role of central tourism organizations. Journal of Destination Marketing \& Management, 17, 100466. https://doi.org/https://doi. org/10.1016/j.jdmm.2020.100466

2. Alastair M. Morrison. (2013). Marketing and Managing Tourism Destinations. Routledge.

3. Alford, P., \& Duan, Y. (2018). Understanding collaborative innovation from a dynamic capabilities perspective. International Journal of Contemporary Hospitality Management, 30(6), 2396-2416. https://doi.org/10.1108/IJCHM-08-2016-0426

4. Almeida-Santana, A., \& Moreno-Gil, S. (2017). New trends in information search and their influence on destination loyalty: Digital destinations and relationship marketing. Journal of Destination Marketing \& Management, 6(2), 150-161. https://doi.org/ https://doi.org/10.1016/j.jdmm.2017.02.003 
5. Aureli, S., \& Baldo, M. (2019). Performance measurement in the networked context of Convention and Visitors Bureaus (CVBs). Annals of Tourism Research, 75, 92-105.

6. Beritelli, P., Bieger, T., \& Laesser, C. (2007). Destination Governance: Using Corporate Governance Theories as a Foundation for Effective Destination Management. Journal of Travel Research, 46(1), 96-107. https://doi.org/10.1177/0047287507302385

7. Beritelli, P., \& Laesser, C. (2019). Why DMOs and Tourism Organizations Do not Really "Get/Attract Visitors": Uncovering the Truth behind a Cargo Cult. https://doi. org $/ 10.6084 / \mathrm{m} 9$. figshare.9924428

8. Bornhorst, T., Brent Ritchie, J. R., \& Sheehan, L. (2010). Determinants of tourism success for DMOs \& destinations: An empirical examination of stakeholders' perspectives. Tourism Management, 31(5), 572-589. https://doi.org/10.1016/J.TOURMAN.2009.06.008

9. Borzyszkowski, J. (2015). The past, present and future of destination management organizations (DMO) - the example of national tourism organizations (NTO).

10. Coban, G., \& Yildiz, O. S. (2019). Developing a destination management model: Case of Cappadocia. Tourism Management Perspectives, 30, 117-128. https://doi.org/ https://doi.org/10.1016/j.tmp.2019.02.012

11. Crouch, G. I. (2010). Destination Competitiveness: An Analysis of Determinant Attributes. Journal of Travel Research, 50(1), 27-45. https://doi. org $/ 10.1177 / 0047287510362776$

12. D'Angella, F., \& de Carlo, M. (2016). Orientation to sustainability and strategic positioning of destinations: an analysis of international tourism websites. Current Issues in Tourism, 19(7), 624-633. https://doi.org/10.1080/13683500.2014.965133

13. Dredge, D., Phi, G., Mahadevan, R., Meehan, E., \& Popescu, E. S. (2018). Digitalisation in Tourism In-depth analysis of challenges and opportunities.

14. European Travel Commission. (2018). NTO Budgets Survey 2018.

15. Gajdošík, T., Gajdošíková, Z., Maráková, V., \& Flagestad, A. (2017). Destination structure revisited in view of the community and corporate model. Tourism Management Perspectives, 24, 54-63. https://doi.org/https://doi.org/10.1016/j.tmp.2017.07.009

16. Galvez, M. D. M., Canadas, J., Haro-de-Rosario, A., \& Caba-Pérez, C. (2020). Exploring best practices for online engagement via Facebook with local destination management organisations (DMOs) in Europe: A longitudinal analysis. Tourism Management Perspectives, 34, 100636. https://doi.org/10.1016/j.tmp.2020.100636

17. Ghanem, M., \& Elgammal, I. (2017). Communicating sustainability through a destination's website: a checklist to inform, motivate, and engage stakeholders. Journal of Travel \& Tourism Marketing, 34(6), 793-805. https://doi.org/10.1080/10548408.2016 .1233928

18. Gunter, U., \& Onder, I. (2016). Forecasting city arrivals with Google Analytics. Annals of Tourism Research, 61, 199-212. https://doi.org/10.1016/j.annals.2016.10.007

19. Hall, C. M., \& Veer, E. (2016). The DMO is dead. Long live the DMO (or, why DMO managers don't care about post-structuralism). Tourism Recreation Research, 41(3), 354-357. https://doi.org/10.1080/02508281.2016.1195960 
20. Hristov, D., Minocha, S., \& Ramkissoon, H. (2018). Transformation of destination leadership networks. Tourism Management Perspectives, 28, 239-250. https://doi. org/10.1016/j.tmp.2018.09.004

21. Hristov, D., \& Petrova, P. (2018a). Destination management plans - a new approach to managing destinations in England: evidence from Milton Keynes. Current Issues in Tourism, 21(2), 133-153. https://doi.org/10.1080/13683500.2015.1070800

22. Hristov, D., \& Petrova, P. (2018b). Destination management plans - a new approach to managing destinations in England: evidence from Milton Keynes. Current Issues in Tourism, 21(2), 133-153. https://doi.org/10.1080/13683500.2015.1070800

23. Hristov, D., Scott, N., \& Minocha, S. (2018). Distributed leadership typologies in destination management organisations. Tourism Management Perspectives, 28, 126-143. https://doi.org/https://doi.org/10.1016/j.tmp.2018.08.003

24. Hristov, D., \& Williams, N. (2018). An examination of DMO network identity using Exponential Random Graph Models. Tourism Management, 68. https://doi. org/10.1016/j.tourman.2018.03.014

25. Hristov, D., \& Zehrer, A. (2019). Does distributed leadership have a place in destination management organisations? A policy-makers perspective. Current Issues in Tourism, 22(9), 1095-1115. https://doi.org/10.1080/13683500.2017.1364715

26. Jabreel, M., Moreno, A., \& Huertas, A. (2017). Semantic comparison of the emotional values communicated by destinations and tourists on social media. Journal of Destination Marketing \& Management, 6(3), 170-183. https://doi.org/https://doi. org/10.1016/j.jdmm.2016.03.004

27. Jose Paul, N. I., \& Varghese, B. (2014). A LITERATURE REVIEW ON DESTINATION MANAGEMENT ORGANIZATION (DMO). ZENITH International Journal of Multidisciplinary Research, 4, 82-88.

28. Klimek, K., \& Marut, D. (2019). Are alpine destination management organizations (DMOs) appropriate entities for the commercialization of summer tourism products? Journal of Destination Marketing and Management, 10, 181-190.

29. Lalicic, L. (2018). Open innovation platforms in tourism: how do stakeholders engage and reach consensus? International Journal of Contemporary Hospitality Management, 30(6), 2517-2536. https://doi.org/10.1108/IJCHM-04-2016-0233

30. Lalicic, L., \& Dickinger, A. (2019). Harvesting tourists' ideas through an idea contest. International Journal of Contemporary Hospitality Management, 31(11), 43804400. https://doi.org/10.1108/IJCHM-01-2018-0048

31. Lalicic, L., Huertas, A., Moreno, A., \& Jabreel, M. (2020). Emotional brand communication on Facebook and Twitter: Are DMOs successful? Journal of Destination Marketing \& Management, 16, 100350. https://doi.org/https://doi.org/10.1016/j. jdmm.2019.03.004

32. Lund, N. F., Cohen, S. A., \& Scarles, C. (2018). The power of social media storytelling in destination branding. Journal of Destination Marketing \& Management, 8, 271-280. https://doi.org/https://doi.org/10.1016/j.jdmm.2017.05.003

33. Mariani, M. M., di Felice, M., \& Mura, M. (2016). Facebook as a destination marketing tool: Evidence from Italian regional Destination Management Organizations. 
Tourism Management, 54, 321-343. https://doi.org/https://doi.org/10.1016/j.tourman.2015.12.008

34. Mariani, M. M., Mura, M., \& di Felice, M. (2018). The determinants of Facebook social engagement for national tourism organizations' Facebook pages: A quantitative approach. Journal of Destination Marketing \& Management, 8, 312-325. https://doi. org/https://doi.org/10.1016/j.jdmm.2017.06.003

35. Milwood, P. A., \& Roehl, W. S. (2018). Orchestration of innovation networks in collaborative settings. International Journal of Contemporary Hospitality Management, 30(6), 2562-2582. https://doi.org/10.1108/IJCHM-07-2016-0401

36. Molina, A., Gómez, M., Lyon, A., Aranda, E., \& Loibl, W. (2020). What content to post? Evaluating the effectiveness of Facebook communications in destinations. Journal of Destination Marketing \& Management, 18, 100498. https://doi.org/https://doi. org/10.1016/j.jdmm.2020.100498

37. Molinillo, S., Liébana-Cabanillas, F., Anaya-Sánchez, R., \& Buhalis, D. (2018). DMO online platforms: Image and intention to visit. Tourism Management, 65, 116-130. https://doi.org/https://doi.org/10.1016/j.tourman.2017.09.021

38. Morrison, A. M. (2013). Destination management and destination marketing: The platform for excellence in tourism destinations. Tourism Review, 28, 6-9.

39. Negrusa, A., \& Coros, M. (2016). DESTINATION MANAGEMENT ORGANIZATION'S (DMO) ROLES AND PERFORMANCE - LITERATURE REVIEW.

40. Niu, Y., Wang, C. L., Yin, S., \& Niu, Y. (2016). How do Destination Management Organization-Led Postings Facilitate Word-of-Mouth Communications in Online Tourist Communities? A Content Analysis of China's 5A-Class Tourist Resort Websites. Journal of Travel \& Tourism Marketing, 33(7), 929-948. https://doi.org/10.1080/105 48408.2015.1075455

41. Nordin, S., Volgger, M., Gill, A., \& Pechlaner, H. (2019). Destination governance transitions in skiing destinations: A perspective on resortisation. Tourism Management Perspectives, 31, 24-37. https://doi.org/https://doi.org/10.1016/j.tmp.2019.03.003

42. Oggionni, T., \& Kwok, L. (2018). A qualitative inquiry of DMO services to hotels: How valuable are they perceived? Journal of Destination Marketing \& Management, 9, 85-96. https://doi.org/https://doi.org/10.1016/j.jdmm.2017.11.003

43. Pike, S. (2007). Destination Image Literature - 2001 to 2007. Acta Turistica, 19(2), $108-125$.

44. Pike, S., \& Page, S. (2014a). Destination Marketing Organizations and destination marketing: A narrative analysis of the literature. Tourism Management, 41, 202-2027.

45. Pike, S., \& Page, S. J. (2014b). Destination Marketing Organizations and destination marketing: A narrative analysis of the literature. Tourism Management, 41, 202-227. https://doi.org/10.1016/J.TOURMAN.2013.09.009

46. Serra, J., Font, X., \& Ivanova, M. (2017). Creating shared value in destination management organisations: The case of Turisme de Barcelona. Journal of Destination Marketing \& Management, 6(4), 385-395. https://doi.org/https://doi.org/10.1016/j. jdmm.2016.06.005 
47. Spasojevic, B., Lohmann, G., \& Scott, N. (2019). Leadership and governance in air route development. Annals of Tourism Research, 78, 102746. https://doi.org/https:// doi.org/10.1016/j.annals.2019.102746

48. Stokłosa, Ł., Marchiori, E., \& Cantoni, L. (2018). Understanding the web maturity of Polish DMOs. Journal of Destination Marketing \& Management, 11. https://doi. org/10.1016/j.jdmm.2018.01.010

49. UNWTO. (2007). A Practical Guide to Tourism Destination Management. In A Practical Guide to Tourism Destination Management. World Tourism Organization (UNWTO). https://doi.org/10.18111/9789284412433

50. UNWTO. (2019). UNWTO Guidelines for Institutional Strengthening of Destination Management Organizations (DMOs) - Preparing DMOs for new challenges. In $U N$ WTO Guidelines for Institutional Strengthening of Destination Management Organizations (DMOs) - Preparing DMOs for new challenges. World Tourism Organization (UNWTO). https://doi.org/10.18111/9789284420841

51. Uşaklı, A., Koç, B., \& Sönmez, S. (2017). How "social” are destinations? Examining European DMO social media usage. Journal of Destination Marketing \& Management, 6(2), 136-149. https://doi.org/https://doi.org/10.1016/j.jdmm.2017.02.001

52. Villamediana, J., Küster, I., \& Vila, N. (2019). Destination engagement on Facebook: Time and seasonality. Annals of Tourism Research, 79, 102747. https://doi.org/https:// doi.org/10.1016/j.annals.2019.102747

53. Villamediana-Pedrosa, J. D., Vila-López, N., \& Küster-Boluda, I. (2020). Predictors of tourist engagement: Travel motives and tourism destination profiles. Journal of Destination Marketing \& Management, 16, 100412. https://doi.org/https://doi.org/10.1016/j. jdmm.2020.100412

54. Wang, Y., \& Pizam, A. (Eds.). (2011). Destination Marketing and Management: Theories and Applications. CAB International.

55. Wight, A. C. (2013). Identifying best practice in national tourism organisations: Lessons for the United Kingdom. Journal of Vacation Marketing, 19(2), 133-148. https:// doi.org/10.1177/1356766712463717 